\title{
ДИДАКТИЧНІ ОСНОВИ ПІДГОТОВКИ ІНЖЕНЕРА-ПЕДАГОГА У ВИЩОМУ НАВЧАЛЬНОМУ ЗАКЛАДІ
}

\author{
Пасічна О. В. Дидактичні основи підготовки інженера-педагога у вищому \\ навчальному закладі. \\ У статті розглянуто техніко-технологічний та психолого-педагогічний складники \\ компетентності інженера-педагога. Акцентується увага на інтегрованому характері цієї \\ професії, на особливостях іï виробничої характеристики. Проаналізовано компоненти \\ професіограми інженера-педагога. Описано принципи й методи професійного навчання. \\ Ключові слова: професійна освіта, інженер-педагог, принципи професійного навчання, \\ методи теоретичного й виробничого навчання.
}

Пасечная Е. В. Дидактические основы подготовки инженера-педагога в высшем учебном заведении.

В статье рассматриваются технико-технологическая и психолого-педагогическая составляющие компетентности инженера-педагога. Акцентируется внимание на интегрированном характере этой профессии, на особенностях ее производственной характеристики. Анализируются компоненты профессиограммы инженера-педагога. Описаны принципы и методы профессионального обучения.

Ключевые слова: профессиональное образование, инженер-педагог, принципы профессионального обучения, методы теоретического и производственного обучения. institution.

Pasichna O. V. Didactic basis of a teacher-engineer training in a higher educational

The author substantiates the urgency of the issue of teacher-engineers training, who carry out educational activity in professional educational establishments. The content of professional education is revealed.

In the article technical-and-technological, psychological and pedagogical components of a teacher-engineer competency are considered. The integrated nature of this profession is highlighted. The components of a teacher-engineer job profile diagram are analyzed.

Pecularities of manufacturing characteristics of teacher-engineers are examined. They include requirements for professional knowledge, skills and abilities in a special engineering field, in the field of training and education.

The principles (polytechnical, relation between teaching and production labour, modelling of professional activities in teaching and learning process, occupational mobility) and methods (of theoretical instruction and industrial training, vocational training) are described.

The author asserts that the use of these principles and methods in the course of teacherengineers training allows to form their professional competence, improve necessary skills and abilities.

Key words: vocational training, teacher-engineer, principles of vocational training, methods of theoretical and industrial instruction.

Модернізація сфери освіти висуває нові вимоги й до професійно-технічної освіти. Закон України «Про професійно-технічну освіту» передбачає створення умов для професійної самореалізації особистості й забезпечення потреб держави у кваліфікованих робітниках. У зв'язку з цим актуальною $є$ проблема підготовки інженерів-педагогів, які здійснюють освітню діяльність у професійних навчальних закладах.

Зміст професійної освіти включає поглиблене ознайомлення з науковими основами й технологією конкретного виду виробничої діяльності. Термін «професійна освіта» розуміють і як сукупність знань, умінь і навичок, оволодіння якими надає можливість працювати 
спеціалістом вищої, середньої кваліфікації або кваліфікованим робітником [1, с. 275].

Головним завданням професійно-технічних навчальних закладів $\epsilon$ формування у студентів теоретичних знань, практичних умінь і професійних навичок. Відповідно, щоб забезпечити якість професійної освіти, викладач повинен володіти на високому рівні професійно-педагогічною компетенцією - здатністю інженера-педагога кваліфіковано здійснювати професійне навчання в межах конкретної спеціальності на рівні вимог, установлених стандартами професійної освіти. Компетентність інженера-педагога містить два інтегровані складники: компетентність техніко-технологічну (інженерну) й компетентність психолого-педагогічну. При цьому техніко-технологічна компетентність $\epsilon$ предметною або змістовою сферою діяльності, тобто тією сукупністю знань, умінь і навичок, яку необхідно передати студенту у процесі здобуття професійної освіти. Психологопедагогічна компетентність є засобом, що забезпечує цей процес [5, с. 286].

На інтегрованому характері професії інженера-педагога акцентується в дослідженнях провідних фахівців із професійної освіти (С. Батишев, В. Безрукова, I. Васильєв, О. Коваленко, 3. Курлянд, Н. Ничкало, М. Сибірська, К. Устемиров, Н. Шаметов та ін.). Науковці наголошують, що педагог професійного навчання повинен досконало володіти i своєю спеціальністю, і засобами навчання й виховання. Досягнути вказаних вимог можна лише за умови, якщо у процесі підготовки у вищому навчальному закладі майбутніх інженерів-педагогів будуть ураховані основні принципи професійного навчання й використані методи, які забезпечують інтеграцію профільного й педагогічного складника цієї професії.

Meта статmi- описати принципи й методи професійного навчання майбутніх інженерно-педагогічних працівників.

Вузловим завданням сучасної методики професійного навчання є його оптимізація, що, за словами О. Коваленко, дозволяє з мінімальними витратами засобів і часу одержати максимальний результат й підготувати кваліфікованого спеціаліста [2, с. 9]. У процесі підготовки інженера-педагога необхідно ураховувати комплекс вимог до професії. Йдеться про професіограму інженера-педагога. У науково-методичній літературі [5, с. 275-285] аналізуються такі складники професіограми інженера-педагога: соціально-економічна, виробнича, санітарно-гігієнічна характеристики професії, вимоги професії до індивідуальнопсихологічних якостей спеціаліста й підготовка кадрів.

3-поміж зазначених складників найбільш важливим, на нашу думку, в аспекті підготовки майбутніх інженерів-педагогів $\epsilon$ виробнича характеристика професії, яка передбачає вимоги до професійних знань, умінь і навичок у спеціально-інженерній галузі (зміст праці в межах тієї професії, за якою здійснюється підготовка студентів; правила безпечного виконання робіт), у галузі навчання (основи дидактики професійної педагогіки; сучасні технології професійного навчання та його методика), у галузі виховання (методи й методичні прийоми виховної роботи зі студентами). Як бачимо, окреслені вимоги зумовлені інтегрованим характером професії інженера-педагога, який одночасно є викладачем i теоретичного, і практичного навчання. У зв'язку з цим у процесі підготовки інженерівпедагогів у ВНЗ необхідно використовувати оптимальні методи навчання, які грунтуються на принципах професійного навчання.

Провідним принципом професійного навчання $є$ політехнічний принцип. Він характеризується відповідністю змісту навчання основним напрямам розвитку сучасної науки й техніки. Як справедливо зазначає Н. Шамрай [3, с. 121-123], реалізація цього принципу потребує дотримання таких умов: зв'язок навчального матеріалу 3 майбутньою практичною діяльністю; урахування чинників, що впливають на продуктивність праці; можливість реалізації пізнавальних інтересів студентів. Політехнічна освіта передбачає оволодіння комплексом знань про наукові основи сучасного виробництва. На основі цих вимог формуються загальнопрофесійні та спеціальні знання студентів.

Крім політехнічного принципу, у процесі підготовки інженера-педагога також ураховуються й інші принципи, а саме: принцип поєднання навчання з виробничою працею, 
зв'язок теорії з практикою (у будь-якому трудовому процесі повинні синтезуватися знання й уміння 3 різних галузей науки; теоретичні знання повинні бути випереджальними й перевірятися на практичних заняттях), принцип моделювання професійної діяльності в навчальному процесі (виявлення типових завдань, їх трансформація в навчально-виробничі завдання), принцип професійної мобільності (зміст професійного навчання повинен швидко вдосконалюватися, ураховуючи інновації у техніці та технології праці).

Розглянувши принципи професійного навчання, зупинимося на методах навчання, реалізація яких у навчальному процесі дозволить майбутнім інженерам-педагогам оволодіти спеціальними знаннями, уміннями й навичками, сформувати основи професійної майстерності. Методи професійного навчання можна диференціювати на 2 групи: методи теоретичного й виробничого навчання. Перша група методів скерована на засвоєння загальнотехнічних та спеціальних предметів. Сюди належать такі методи: словесні (усний виклад матеріалу, бесіда, робота з книгою), наочні (ілюстрації, демонстрації), репродуктивні та проблемно-пошукові (розв'язання типових i творчих, пізнавальних завдань), активні (дидактичні й ділові ігри, інтегративні заняття) та ін. Реалізація окреслених методів дає можливість студентам засвоїти теоретичні основи майбутньої професії, розвинути абстрактне мислення, навчитися проводити аналогії, встановлювати причинно-наслідкові зв'язки, вести активну пошукову діяльність. Друга група методів зорієнтована на досягнення головної мети виробничого навчання - формування у студентів професійної майстерності.

За словами I. Левіної [4, с. 148-149], ця мета конкретизується низкою завдань, розв'язання яких стосується змісту поняття «професійна майстерність», як-от: якість виконання роботи з урахуванням технологічних вимог, продуктивність праці, здатність самостійно приймати рішення, творче ставлення до праці тощо. Означені компоненти професійної майстерності зумовлюють необхідність використання у навчальному процесі передовсім таких методів: показ прийомів трудових дій (викладач демонструє кожний складник трудової дії), вправи на тренажерах задля відпрацювання правильності та швидкості виконання трудових дій, самостійні спостереження студентів (порівняння даного устаткування з іншими об'єктами 3 урахуванням відомих вимог та нормативів), письмовий інструктаж (застосування інструктивно-технологічних карт та алгоритмів для виконання комплексних робіт, регулювання складного обладнання) та ін.

Отже, використання окреслених методів у процесі підготовки інженерів-педагогів дозволить сформувати у них професійну компетенцію, удосконалити необхідні вміння й навички, розвинути такі важливі виробничі якості, як самостійність, активність, творче ставлення до праці.

\section{Література}

1. Гончаренко С. У. Український педагогічний словник / Гончаренко С. У. Київ : Либідь, 1997. - 376 с. 2. Коваленко О. Е. Методика професійного навчання : [підруч. для студ. вищ. навч. закл.] / Коваленко О. Е. - Харків : Вид-во НУА, 2005. - 360 с. 3. Профессиональная педагогика: [учеб. для студ. пед. специальностей]/ под. ред. С. Я. Батышева. - Москва : Ассоциация «Профессиональное образование», 1997. - 512 с. 4. Теорія і методика професійної освіти : [навч. посіб.] / [3. Н. Курлянд, Т. Ю. Осипова, Р. С. Гурін та ін.]. - Київ : Знання, 2012. - 390 с. 5. Устемиров К. У. Профессиональная педагогика: [учеб. для студ. вузов] / Устемиров К. У., Шаметов Н. Р., Васильев И. Б. Алматы, 2005. - 432 с. 